\title{
Future Legal Issues in Medical Research and Technology: The Obligations of Researchers in the Light of Recent Developments in Genetic Testing
}

\author{
Scott Guy, BA, LLB, Barbara Ann Hocking*, BA, LLB, LLM, PhD, \\ Stewart Muirhead, LLB
}

\section{INTRODUCTION}

In an earlier paper in this Journal, we examined the fundamental principles of negligence and the approach taken in recent Australian decisions in setting out boundaries to any categorisation of a fiduciary relationship between doctor and patient. In this paper we focus on the scope of the doctor-patient relationship and the extent of the medical practitioner's duties in this relationship. The boundaries of the medical relationship have raised a number of important ethical and legal concerns. For example, does a patient have a right of access to his or her medical records on the basis of a fiduciary relationship that exists between the doctor and the patient?

Our contention in this paper is that the scope or boundaries of the fiduciary relationship duties owed by medical practitioners will become even more significant in view of recent developments in genetic testing. Genetic testing allows the medical profession to determine if a pre-disposition to develop disease exists prior to the onset of such symptoms as breast and ovarian cancer. However, this raises the central issue as to who should have control of these records of diseased people. Will a plaintiff be able to rely on a doctor's fiduciary duty to his or her patients in order to gain access to genetic records?

It will be further suggested that genetic technology also raises important ethical and legal issues of confidentiality and discrimination. A situation may increasingly become common where commercial organisations screen clients or customers on the basis of

\footnotetext{
* To whom correspondence should be addressed: School of Justice Studies, Faculty of Law, Queensland University of Technology Faculty of Law, Brisbane, Queensland, Australia, 4059.

Email: b.hocking@qut.edu.au
}

their genetic susceptibility to diseases or a particular medical condition. In this context, we focus attention on the insurance industry and address the question as to whether insurers can refuse insurance on the basis of a genetic predisposition to a particular condition or disease.

These issues will undoubtedly become major aspects of litigation in the future. In this paper, we attempt to develop the doctrine of fiduciary duties to deal with these unresolved issues and potential future causes of action.

\section{ACCESS TO MEDICAL RECORDS AND GENETIC DATA}

An important issue in recent medico-legal debates concerns the scope of the doctor-patient relationship and the extent of the medical practitioner's duties in this relationship. For example, does the medical practitioner's duty of care extend beyond the treatment of a patient to providing access to his or her medical records? That is, do patients have a right to their medical records on the basis of the fiduciary relationship that exists between the doctor and patient?

The boundaries of the doctor-patient relationship and the patient's right of access to medical records were explored in the relatively recent Australian High Court in Breen -v- Williams. This decision approached the doctor-patient relationship narrowly. It was held that the patient's medical records were the medical practitioner's intellectual property and therefore the patient had no legal right to her records. The patient, Ms Breen, contended that the previous Australian High Court decision, Rogers -v- Whitaker, endowed her "with a right to know" which extended to a right of access to the entire record of her attending doctor. In 
other words, the fiduciary relationship that existed between herself and Dr Williams went beyond her medical treatment to any written records that were associated with her case.

This argument was dismissed by Dawson $\mathrm{J}$ and Toohey $\mathrm{J}$ who held that the decision in Rogers - $\mathrm{V}-$ Whitaker did not seek to extend the fiduciary duty to one which allows the patient a right to his or her medical records. Meagher JA, who is co-author of an authoritative text on the subject, commented that no basis could be found in the equitable doctrine of fiduciary duties for Ms Breen's claim to access to her records.

The scope or boundaries of the fiduciary duties owed by medical practitioners will become even more significant in view of recent developments in genetic testing. In brief, genetic testing enables the medical profession to determine if patients have a predisposition to develop particular conditions or diseases. However, the process of genetic testing would appear to raise the central issue as to who should have control of these records of deceased people. Will a plaintiff be able to rely on a doctor's fiduciary duty to his or her patients in order to gain access to genetic records? On the basis of Breen v. Williams, it would appear that a patient would have no such right of access to his or her records.

\section{NEW GENETIC TECHNOLOGIES AND ETHICAL CONSIDERATIONS}

In Breen -v- Williams the Australian High Court also considered the extent of the medical practitioner's fiduciary duty to his or her patient. The court refused to accept that the entire doctor/patient relationship should be fiduciary in nature. However, aspects of the judgement of Dawson and Toohey JJ would tend to emphasise a broader conception of the medical practitioner's fiduciary obligations to his or her patients. In particular, their Honours identified a duty of confidentiality owed to the patient, a duty to avoid a conflict of interests, as well as a presumption that where a medical practitioner receives substantial benefit in excess of proper remuneration it is as a result of undue influence.

It is suggested that these fiduciary duties may, in future, affect a medical practitioner's use of a removed tissue or genetic information. If, for example, a medical practitioner was to receive remuneration from the patenting of an invention derived from donated biological material, then the medical practitioner will have a conflict of interest which, as a result, would lead to a breach of fiduciary duty.

This raises the further issue as to the ethical duties and obligations of medical researchers and commercial organisations, as opposed to medical practitioners, that have obtained human genetic material. It has been argued that the ethical and legal obligations of a medical researcher should be higher than a treating medical practitioner because participation of the patient in research is voluntary and without immediate benefit to the patient. It is suggested that the relationship between a commercial organisation (which comes into possession of biological material) and the individual who provided it, is not fiduciary in nature unless the commercial organisation obtains that material directly from the source. Accordingly, the commercial user who receives the material indirectly will not be under a duty of confidentiality to the source but will be bound by privacy legislation. Nor will there be a conflict of interest with the source (ie the patient) if it receives profits from a patenting invention that uses the biological material.

While this situation is alarming, a recent UK authority (which provides some guidance in Australia) considers the proposition that the duty of confidentiality of a medical practitioner or researcher will not be breached where commercial use is made of deidentified (anonomised) data without the consent of the source of that information. The UK Court of Appeal held that anonomised information can be sold to commercial third parties without liability provided that the personal privacy of the information is protected.

\section{Ethical standards}

The Australian National statement on ethical conduct in research involving humans (1999) deals in detail with the use of human tissue samples and human genetic research. However, there is little treatment of the issue of consent to commercialisation of biological material. Principle 19 of the National statement acknowledges that some research involving humans "may be intended for, or later directed towards, purposes of commercial exploitation". It also stipulates the general principle that disclosure of interests by researchers should be made to the Human Research Ethics Committee, and that the consent of participants should be obtained. Whilst there are no specific provisions in the National statement dealing explicitly with issues of disclosure and consent in respect of commercial use of biological samples, it has been stated that the National statement can be interpreted as supporting the need for full disclosure and specific consent from the subject to potential commercial users of their tissue samples.

\section{INSURANCE}

\section{Genetic technology and the insurance position}

The human genome project and other genetic research are creating scientific, legal and ethical issues 
of major international importance. Issues associated with genetic screening are arguably the greatest challenges to our legal system. The potential for screening raises legal and ethical concerns. One of those concerns is the issue of confidentiality and discrimination. These problems are particularly acute in the insurance industry and in the workplace. For example, can insurers refuse insurance on the basis of genetic susceptibility to a particular disease? Such areas have the potential to become major aspects of litigation in the future. It is arguable that because there are so many factors responsible for people's health, insurance companies will soon realise that genetics is not a very useful tool for assessing risk. If too many factors are taken into account, insurance may be unaffordable, which in turn would considerably reduce insurance companies' income.

\section{Financial interests and dishonesty}

There are strong ethical overtones which arise in the legal profession, which have commonly been dealt with in the context of insurance. For the legal profession (in comparison to the medical profession) who obtain their insurance on the open market, the terms and conditions of those policies are more stringent where the insured is seen to have been dishonest, fraudulent or involved in some criminal or malicious act. It is not uncommon to find that most policies will only cover an insured for breach of professional duty "in the conduct of the business ... of the insured in a professional capacity". Unless the insured has opted for an extension to cover claims arising out of dishonesty, any such claim amounting to dishonesty will be excluded under the policy.

A common type of dishonesty exclusion clause relates to claims "brought about or contributed to by any dishonest, fraudulent, criminal or malicious act or omission of the insured (or their predecessors in business) or of any person at any time employed by the insured (or their predecessors in business)". The authors are aware that some policies will even exclude circumstances where the insured has been "in reckless disregard for the consequences".

So how does the exclusion clause work in practice? This was tested in the New South Wales Supreme Court decision of Murphy \& Allen -v- Swinbank. This case involved allegations that a firm of solicitors (engaged by managers of a mortgage trust) acted for the trustees in the trust in respect of a number of loans made by the trust. The solicitors were involved in two loan transactions, one in November 1995 for approximately $\$ 20$ million, and a second loan for \$14 million, both relating to the purchase of 2 properties. The arrangements included an equity sharing agreement which entitled the company to $50 \%$ of the development. The solicitors provided certificates to the trustee company enabling the funds to be advanced, but no mention was made of the equity sharing arrangement. Indemnity was in issue and the insurers raised a number of defences. Relevant here, the insurers relied upon the dishonesty exclusion clause which read:

"This insurance shall not indemnify the insured in respect

of any liability brought about by the dishonest or fraudulent

act or omission of the insured including any partner or former

partner of the insured or any person employed in connection with the practice."

Einstein J considered the definition of "dishonesty" as "discreditable, as being at variance with straightforward or honourable dealing; underhand, fraudulent, thievish, connivish." He concluded that it was not necessary to show that the solicitors had any intent to be dishonest but that breach of duty, including fiduciary duties, owed by a solicitor to a client could be sufficient. The failure to adhere to professional standards will amount to dishonesty if the standards involve an express obligation to attest to the truthfulness of a matter.

The judge also held that the solicitors' conduct fell within the description of "discreditable" as being at variance with straightforward or honourable dealing. His Honour held that a number of steps taken by the senior partner included deliberate false representation which was in breach of his fiduciary obligations. It also involved a degree of moral turpitude or delinquency which went well beyond and transcended breach of duty.

Professionals who take their insurance on the open market must adhere to a high standard of care. The insurers are not likely to entertain claims where there is the slightest degree of recklessness. Murphy and Allen -v- Swinbank affirms that there need not be an intent to be dishonest or fraudulent but that a failure to adhere to professional standards, particularly if there is a duty to pass on information to a client, may objectively amount to dishonesty.

In McCann -v- Switzerland Insurance Australia Limited the facts involved a solicitor taking a secret commission from money placed with the solicitor to invest in a "prime bank instrument" in the international money market. Whilst the solicitor took a secret commission, he did purport to place an investment on the international money market, where it was stolen by a third party. The issues were two-fold. Firstly, whether the solicitor's conduct was dishonest or fraudulent, and secondly, whether the liability was "brought about by" such act or omission. The court held that both issues should be determined against the claimant and hence indemnity did not lie under the policy. The court determined that the solicitor had acted dishonestly and 
fraudulently as he had consciously preferred his interests to those of his clients.

The contentious issue was whether or not the loss was "brought about by" his actions, since it was not the solicitor's act but the theft by the third party which created the loss. In determining "brought about by" the court found that there was a sufficient casual nexus between the placement of the funds and the loss to satisfy the exclusion. The fiduciary duty of solicitors is far-reaching, considerably more so when compared to that of the medical profession. Traditionally, fiduciary duties have been concerned with the protection of monetary interests, the courts have been reluctant to extend the medical practitioner's fiduciary obligations to personal interests as this traditionally was not perceived as a problem by the courts.

The issue of dishonesty has also been considered by the courts in the United Kingdom. In the recent decision of Royal Brunei -v- Tan Lord Nicholls held that the test for dishonesty was an objective one: "If a person knowingly appropriates another's property, he will not escape a finding of dishonesty simply because he sees nothing wrong in such behaviour ... nor does an honest person in such a case deliberately close his eyes and ears, or deliberately not ask questions, lest he learn something he would rather not know and then proceed regardless."

It has been argued that this test provides two conflicting definitions. Firstly, there is the negative definition: an honest person does not take another person's property without asking, and does not participate in a transaction if he knows that someone will unfairly lose out as a result. Secondly, there is an idealistic extension of that negative definition: the standard is what an honest person would have done in the circumstances.

In the United Kingdom, at common law a cause of action cannot be founded on the defendant's dishonourable behaviour per se, as there is no generalised tort of fraud. However, common law will stop a cause of action which is contrary to public policy. In equity, the approach to dishonesty pays less regard to the defendant's state of mind and more to the circumstances of the claimant's loss. The crucial distinction between the two in determining dishonesty is that the common law will ask "what did the defendant actually do?" whereas equity asks "what should he/she have done?"

\section{CONCLUSION}

In short, ethical standards continue to define the duties of the medical profession and appear to be more onerous than legal standards, in some respects. Both access to records and disclosure of information in the doctor-patient and third-party relationship continue to trouble the common law and the courts. It is timely that we set about developing the doctrine of fiduciary obligation to resolve the many and presently unanswered questions in relation to such issues as those involving access to medical records and the disclosure and use of a patient's genetic information.

\section{REFERENCES}

1. Lawrence Berkeley National Library. What is Genetic Testing? Accessed 10 March 2004. http://www.lbl.gov/Education /ELSI/Frames/genetic-testing-f.html

2. Roy DJ, William JR, Dickens BM. Bioethics in Canada. Scarborough: Prentice Hall Canada, 1994.

3. Wertz DC, Fletcher JC, Berg K. Guidelines on Ethical Issues in Medical Genetics and the Provision of Genetic Services. Geneva: WHO, 1995.

4. Flanagan W. Genetic Data and Medical Confidentiality. Health Law Journal 3: 269; 1995.

5. McInerney v. MacDonald [1992] 2 S.C.R. 138.

6. Privacy Commissioner of Canada. Privacy Legislation in Canada. Accessed $10 \quad$ March 2004. http://www.privcom.gc.ca/fs-fi/02_05_d_15_e.asp

7. Personal Information Protection and Electronic Documents Act, Statutes of Canada 2000, c.5.

8. Personal Health Information Act, S.M. 1997, c. 51.

9. Ombudsman Manitoba, Access and Privacy Division. The Personal Health Information Act. Accessed 10 March 2004. http://www.ombudsman.mb.ca/phia.htm.

10. R.S.Q., chapter A-2.1.

11. R.S.Q., chapter P-39.1.

12. Canadian Medical Association. Code of Ethics of the Canadian Medical Association, 1996. Accessed 10 March 2004. http://www.cma.ca/cma/common/displayPage.do?pageId=/stati cContent/HTML/NO/12/where_we_stand/1996/10-15.htm.

13. R.S.O. 1990, c. H.7, s. 26.

14. Ontario Regulations 559/91, and amendments under the Health Protection and Promotion Act. 2003.

15. Pennison v Provident Life and Accident Insurance Company, 154 So. 2d 617 (La. Ct. App. 1963), certa. Denied 156 So. 2d 266)

16. Mikel v Abrahams, 541 F. Supp. 591 (W.D. Mo. 1982)

17. Curry v. Corn, 277 N.Y.S. $2 d 470$ )N.Y. Misc. 1977).

18. Khairzdah v Khairzdah, 464 So. 2d 1311 (La. Dist. Ct. App. 1985)

19. MacDonald vs. Clinger, 446 N.Y.S.2d 801 (N.Y. App. Div. 1982).

20. Suter S. Appendix C: Case Law in Mapping Public Policy for Genetic Technologies, 1998. Accessed 10 March 2004. http://www.ncsl.org/programs/health/genetics/BOOK/appendc.htm

21. Diderikx v Cottage Hospital Corp. 393 N.W. 2d 564 (Mich Ct. App. 1986).

22. Elliott R. After Currier: Canadian Criminal Law and the NonDisclosure of HIV-Positive Status. Montreal: Canadian HIV/AIDS Legal Network, 1999.

23. Tarasoff $\mathrm{v}$ Regents of the University of California (1974), $529 \mathrm{P}$. 2d 533 (Cal. Sup. Ct.); (1976), 551 P. $2 d 334$ (Cal. Sup. Ct.).

24. Miller J. Physician-Patient Confidentiality and Familial Access to Genetic Information. Health Law Journal 2:14; 1994.

25. Tanner v. Norys [1980] 4 W.W.R. 33.

26. Wenden $v$ Trikha (1991), 116 A.R. 81; aff'd (1993), 14 C.C.L.T. (2d) 225 (Alberta C.A.). 
27. Pittman Estate v. Bain (1994) 112 DLR (4th) 258 Ontario Central Division.

28. Smith v. Jones, 169 D.L.R. (4th) 385 (S.C.C.), 1999.

29. Ontario Child and Family Services Act R.S.O. 1990, c C.11.

30. Ontario Highway Traffic Act, R.S.O. 1990, c H.8.

31. The Quebec Charter of Human Rights and Freedoms, R.S.Q. C12.

32. Pate v. Threlkel, 661 So.2d 278 (Fla. 1995).
33. Safer v. Pack, 677 A.2d 1188 (N.J. Super. 1996)

34. President's Commission for the Study of Ethical Problems in Medicine and Biomedical and Behavioral Research. Screening and Counseling for Genetic Conditions. Washington DC: The President's Commission, 1983.

35. Genetics in Health Care: Report 42. Ottawa: Minister of Supply and Services Canada, 1992.

Scott Guy is a PhD student at the University of Queensland, School of Law, Brisbane, Queensland, Australia

Babara Hockings is a senior lecturer at Queensland University of Tecchnology, Faculty of Law, Brisbane, Queensland, Australia. She is the vice-president of the Association of Canadian Studies in Australia and New Zealand (ACSANZ). 